\title{
Needed Developments in Junior College Libraries
}

Walter Crosby Eells is executive secretary of the American Association of Junior Colleges, Washington.

TEEDED improvements and developments in junior college libraries and library services which it seems to me are reasonable to look forward to in the next two or three years may be considered under the following heads: development of library consciousness on the part of administrators, compilation of information on junior college libraries, improvement of book collections, improvement of periodicals, greater emphasis on library service, better library tools, increased recognition of staff, evaluation of libraries, and organization of a library section in the American Association of Junior Colleges.

\section{Library Consciousness}

Perhaps first in importance I would place a development of a greater consciousness on the part of administrators and boards of education, who are largely responsible for college financial policies, of the importance of the library as an essential and integral part of the junior college. I am sure there has been a marked improvement in this respect in the past five years. The work of the Carnegie Advisory Committee on Junior College $\mathrm{Li}$ braries certainly served to call attention of administrators as never before to the significance of this part of their institutions.

This year the American Association of Junior Colleges has been preparing an extensive reference work, American Junior Colleges, occupying more than 700 pages. ${ }^{1}$ It is being published as a companion volume to the fourth edition of American Universities and Colleges. It contains comprehensive information on approximately five hundred accredited junior colleges. This information, for the most part, has been furnished by the administrator of the institution. One question asked was, "What is the greatest problem facing your institution today?" Almost 400 "greatest problems" were stated, most of them as might be anticipated dealing with questions of finance. To my mind, however, it is indicative of a significant growing consciousness of library problems that, in the case of 20 institutions, some problem connected with the library was selected. A few examples may be given: "Additional room for growing library," "need of separate library building," "need of extensive additions to library," "more books, periodicals, and magazines needed," "library facilities inadequate; institution badly in need of a library," and "college particularly in need of a library building in order to take care of the student body as it should be cared for." Most of the problems stated involve additional space or new buildings, but the need for greater facilities and improved and extended service is also recognized. These statements and others not quoted come from publicly \footnotetext{
1 Eells, W. C. ed. American Junior Colleges.
American Council on Education. Washington, I 940. $\$ 3.50$.
} 
controlled and from privately controlled junior colleges; from those for men, for women, and for both sexes; from junior colleges for whites and for Negroes. They range geographically from Vermont to California, from Minnesota to Texas. They are evidence of a desirable growing administrative consciousness of the importance of the library in the fully functioning modern junior college. I doubt whether a similar inquiry ten years ago would have shown nearly as much evidence of such administrative recognition.

Recently I visited a junior college where the administrator showed me the relatively new library unit, confessing that already the seating capacity was sufficient for only a small fraction of the student body, and almost.naively remarked, "It is surprising how important the library is becoming in junior college education!" We need a greater development of such administrative consciousness before library buildings or wings are built, not afterward!

\section{Library Information}

In order to know where we stand and to furnish information to administrators, board members, and the supporting clientele, we need extensive comparative information regarding junior college library conditions and developments throughout the country. The Carnegie Advisory Committee collected a wealth of significant data concerning junior college libraries, but unfortunately it has never been published. A volume somewhat like Dr. Randall's The College Library was contemplated, but has not been prepared and the data, collected five years ago, are now somewhat out of date. As far as I know the only summary of this data ever published consists of the preliminary summary and percentile tables covering cer- tain features which I compiled and published in the Junior College Journal for January 1936.

Much briefer information has been collected this year for publication in American Junior Colleges. The following information was asked of each of the 500 accredited junior colleges :

I. How is the library housed (e.g., separate building, one room in a building, etc.) ?

2. Seating capacity of reading room or rooms.

3. Number of volumes.

4. Volumes added, I938-39.

5. Number of current periodicals regularly received.

6. Amount of budget for $1939-40$ for library purposes, excluding library staff salaries.

7. Number of librarians: Full-time

$$
\text { Part-time }
$$

8. Equivalent of part-time librarians in full-time units.

9. Decribe briefly any special collections or features of particular value.

As far as this information was given, it will be found in the reference volume which is now in press. It should furnish a valuable source of information for comparisons with your own institutions. Time has not permitted preparation of comprehensive or interpretative summaries, but I hope that these may be made in our office and published in the Junior College Journal next year.

\section{Book Collections}

Probably few if any of this group will question that their book collections are decidedly inadequate to the needs of their institutions-to the legitimate calls made upon them, or that should be made upon them, both by students and faculty. How can they be improved? What books should be added? How shall they be selected? Nothing will take the place of 
intelligent judgment on the part of librarian and instructors in choice of new titles. These individuals are so busy with a multiplicity of other duties, however, that it is not always easy or possible for them to keep up with recent publications even in a restricted field. They need the help of buying lists, book reviews, and similar aids. It is not necessary for me even to suggest the well-known library tools for this purpose. You are already familiar with them and I trust are using them constantly.

I do wish to discuss briefly, however, some points concerning the latest and most comprehensive tool for this purpose designed especially for junior college libraries. I refer, of course, to that important outcome of the Carnegie committee's work, Mohrhardt's List of Books for Junior College Libraries.

Many junior college librarians have told me that this has been exceedingly valuable, when used as it should be, as a suggestive list of titles for consideration, not slavishly as a definite buying list without reference to particular local needs. This volume was published in 1937. No titles are given of books published later than 1936. The question may be raised as to how soon it may be desirable to ask the Carnegie Corporation or the American Library Association or some other agency to prepare a supplement of more recent titles. I suggest that discussion by this group and a recommendation from it might be the most effective way to bring the need for such revision to the attention of the proper authorities. The somewhat analogous Shaw list of books for senior college libraries was published in I93I; an extensive supplement of 284 pages has just been issued this spring. Should the Mohrhardt list wait a similar length of time or is there need for a five-year revision? Or, if not a complete revision, is there need for a supplementary list of titles at the end of five years, followed by a possible ten-year complete revision?

I feel there is another very serious limitation in the Mohrhardt list. The American Association of Junior Colleges has recently received a grant from the General Education Board for an exploratory study in the field of terminal education in the junior college. Our preliminary studies already show that less than half of the students who enter junior colleges graduate from them; that less than half of those who graduate continue their formal education beyond junior college. Thus the junior college is a "terminal" institution as far as formal education is concerned for considerably over threefourths of its students. Junior colleges are waking up to this fact and are stressing more and more the importance of significant semiprofessional courses. Here are a few that are being offered in different junior colleges: accounting, agriculture, aviation, banking, bookkeeping, business, library assistantship, commercial art, dental assistantship, decorating, design, drama, engineering technology, finance, forestry, home administration, hotel and restaurant management, journalism, medical secretaryship, merchandising, music, nursing, policing, public health sanitation, radio, photography, recreational leadership, secretarial work.

For how many of these fields does the Mohrhardt book give any satisfactory list of titles of books or periodicals that are helpful as supplementary or as supporting material? An examination of the twentyfour main groups of that list will show that they are outlined almost entirely in terms of academic rather than vocational 
and semiprofessional fields. Committees of the important groups in business education and home economics, for example, which are working with us in this important terminal study, have called attention to the extreme paucity of helpful material in the Mohrhardt list and are undertaking to compile lists of important books in their particular fields. Our commission would be glad to receive your judgment as to whether this type of activity should be extended to other fields. If so, how should it be published? We contemplate the publication of special monographs in the fields of business education, home economics, engineering and technology, agriculture, medical secretaryship and other subjects. Should suggested library lists be published in these monographs, or should they be gathered in a separate publication as a semiprofessional supplement to the Mohrhardt list?

\section{Periodicals}

The world is changing so rapidly that even the very latest books are not new enough to keep up to date with recent developments and with corresponding junior college needs. This function can only be met by a well-chosen group of periodicals. What are the best periodicals? What constitutes a well-selected, diversified list? Is it desirable to have a scale for evaluation of periodicals for junior college purposes? Dr. Adams, in a list published in the Junior College Journal in March 1939, furnished a frequency list of $\mathrm{I} 89$ periodicals actually taken by 5 or more of the 136 junior college libraries reporting. How valuable are these periodicals? Can frequency be taken as a measure of relative value? These are important questions.

Possibly many if not most of you are familiar with the scale for evaluation of I27 periodicals for secondary school libraries devised by the Cooperative Study of Secondary School Standards and used by it in the evaluation of several hundred secondary school libraries in every state in the union. Incidentally, I may say that this scale proved to be one of the best measures we had for determination of the general quality and value of a library. This scale was published in the Wilson Bulletin for Librarians in June 1937.

Since devising this scale, I have frequently wondered whether it would be desirable to construct a similar scale for the evaluation of the periodical collections of junior college libraries, not only as an evaluative instrument but as a suggestive guide for periodical subscriptions as well. The expense would not be great and I think there is a possibility, if not a probability, of securing the necessary funds if you feel such a scale would be of real value to the junior college librarians of the country.

If it is decided to construct such a scale there are numerous questions that need to be considered-the list of periodicals to be evaluated, the selection of the jury, and adjustments for various types of institutions (for example, for institutions for men and for women, for Catholic and Protestant junior colleges, for urban and rural institutions, etc.). If your group, after frank and critical consideration, feels like asking the American Association of Junior Colleges to undertake the construction and publication of such a scale, I am sure it could help materially by a formal endorsement of the proposal and by the selection of an advisory committee to work with us in the task. In the construction of the secondary school scale we learned 
some things that would make it possible to construct a better junior college scale. My own rather superficial and impressionistic judgment is that most junior college libraries leave much to be desired in the way of a satisfactory working collection of current periodicals.

\section{Service}

I am confident that this group needs no argument in support of the statement that the primary object of the library is not equipment but service, even though many of the statements of standards have stressed this fundamental consideration little if at all. I am sure this group is more than familiar with the story, hoary with age, of the Harvard librarian, a century or more ago, who had every book belonging to the library on the library shelves except one, and was then on the way across the Harvard yard to get the missing volume from Professor Agassiz. It is assumed, of course, that this represents an ideal of library service which even if it were true a century or more ago, is considered absurd today. Now we think of the library as a work shop, not a museum; as a dynamo, not a depository; as a tool, not a tomb. Or do we?

That the ancient Harvard innuendo, if it were ever true, may not be entirely outdated even in the year 1940 is strikingly illustrated by a library recently evaluated by the Cooperative Study of Secondary School Standards. True, this was in a private secondary school, not in a junior college, but it is a school which has given some consideration to expansion into the junior college field. This school, located in one of our large cities, and consisting of between two and three hundred boys, approximately half boarding and half day students, was carefully stud- ied by the cooperative study this spring. The library is open only three periods a day-from 2 :O0 to 3 :00 P.M., from 5 :00 to $6: 00$, and from $8: 00$ to $9: 00$. The only students who are permitted to enter it during the 2 :OO P.M. period are those who are on the dean's list-approximately Io per cent of the student body. It is open to other students the other two periods, but the day students all go home at $3: 30$, and cannot therefore use the library at all (if they are not on the dean's list), unless they return for one of the inconvenient evening hours. Needless to say, practically none of them do so. The library has seats for thirty, but twenty of these seats are carefully roped off because the furniture is too choice to permit its use by average healthy American boys. The library specializes in de luxe editions, beautiful bindings, choice volumes-some too choice for ordinary boys to be permitted to touch except under special supervision. The librarian exhibited to the examiner a recent volume on rice paper which he said he had not yet allowed any of the boys to handle. A set of the Harvard classics (note the Harvard note in this tale!) was placed on shelves so high that neither students nor adults could reach them without a ladder.

Not a word of this description is overdrawn. More revealing details could be given if time permitted, but these are sufficient to suggest that the allegedly ancient Harvard concept of the library as a cold storage plant has not vanished entirely even from some of our best (!) schools in the year 1940. This library may be a collector's paradise, but not a school library. Its basic assumption appears to be that books are far more valuable than boys! The librarian is a great lover of books. 
I would stress then the importance of greater service to faculty and student body as a whole. This has been said to you before, and I am confident it is needless to repeat it here. There is one aspect of the matter, however, which I think may not have been sufficiently emphasized in your thinking. I have already mentioned the new study of junior college terminal education, and indicated that less than one-fourth of junior college students ever continue their formal education beyond the junior college. Perhaps even that figure is too generous. I gave the commencement address last week at a large public junior college which was celebrating its twenty-fifth anniversary-not a common occasion as yet in the public junior college field. The announcement was made that over 19,000 students had been enrolled in the institution since its organization but that only 4000 of them had graduated. My estimate of three-fourths terminal is distinctly too low in this case. My plea, then, is for you to consider the special needs of the student who is not going on to advanced work in the university.

You ought of course to see that the minority who do go to the university are equipped to use intelligently the more extensive university library for research and for advanced study; but if you should fail in this important obligation, the student still has another opportunity to make up for your deficiency when he gets to the university.

I am more interested, however, in your obligation to the great majority of your students who may never see the inside of a university library. Yours is their last school opportunity to learn to use and love a library. Yours is the opportunity to give these terminal students a concept of li- brary methods, a knowledge of library machinery, and above all a taste for the resources of the library as a matter of general culture. Will your students turn naturally to the resources of the public library for leisure time reading and for special study when they graduate (or "quituate") from the junior college? Undoubtedly the junior college will mark the completion of formal general education for increasing thousands of young people in the next few years. Is their general education complete if they have not acquired a library taste, a library consciousness, a library habit? What is your obligation in the matter?

In this connection I suggest the appointment of a committee representing various library interests to cooperate with our Commission on Junior College Terminal Education in the library aspects and implications of its work.

\section{Tools}

Comprehensive bibliographies are among the tools of the librarian. It is not my purpose here to discuss bibliographies in general, but to report briefly concerning one very important new bibliography, now in process of construction, which I feel sure many of you should find very useful. As the foundation for our extensive study of junior college terminal education, already mentioned, we feel the first essential is a comprehensive, classified, fully annotated bibliography of everything of significance that has been published in this field.

Frances Shimer Junior College was generous enough to lend its librarian to the commission on terminal study for six months to construct such a bibliography. Incidentally, when I selected Miss Engleman for this service I was not aware that 
she was also secretary of this division of the American Library Association. I am glad to have this evidence that you and we agree on her capability! If it would not embarrass her too much I should like to tell you much more of the outstanding work she has done in our office at Washington since the first of March. I hope instead you will give her the opportunity to tell something of her own work, if not of the worker.

Suffice it to say the bibliography, when completed, will consist of more than a thousand titles and will, I trust, justify the work, the thought, and the cost which have gone into its making. I hope it will be of real value as a further junior college library tool when it is published this fall.

\section{Staff}

That the librarian should be well educated, professionally trained, physically strong, and passionately fond of service goes without saying, particularly before such a representative group as this. Perhaps one of the greatest needs is a fuller recognition on the part of administrators and school boards of the professional status of the librarian and of a salary commensurate with that status. I am sure that all of you are imbued with the ideal of service sketched so inadequately in a previous section, but often you lack the time necessary for its realization. The spirit is willing but the flesh is weak. You are so encumbered with a mass of detail that you do not have time for the extra reading, the conferences with faculty members, the assistance to students, the cultivation of reading habits on the part of students, for which your professional training has fitted you.

I realize that in many cases the salary of the librarian is not commensurate with that of other members of the staff with equivalent professional training. This should be remedied. I believe there is evidence that it is being remedied. But I am going to make the paradoxical statement that in my judgment many of you are now overpaid, not underpaid, for the work you are doing! Lest I make myself unanimously unpopular and you regret ever asking me to speak to you today, let me hasten to explain this statement. In all too many cases you are receiving salaries (even if adequate) for professional work, when you are actually spending a large part of your time in clerical work, in work which could be done efficiently by a library clerk or assistant paid considerably less. What I am pleading for is that you be given time to do a professional job of librarianship-and that you receive salaries appropriate to that professional level. I have seldom seen a junior college librarian (or any other for that matter) who was not overworked, but I am not sure the overwork was always on the professional level.

Of course the detailed work which makes up a large percentage of the actual working time of the effective library must be done. My plea is not to you, who I am sure need no convincing on this matter, but to your administrators for a better knowledge of the whole field of library work and administration at its varying levels. You must be free for service on a truly professional level. The concept of the librarian as mere custodian and clerk must give place to a much higher one of counselor and consultant.

\section{Evaluation}

Occasional evaluation of a school or of particular units of it is exceedingly valuable not only to enable us to see where 
we stand but more important to suggest desirable lines of further progress and to furnish a stimulus for such improvement. I am impelled to speak of this because of my experience for four years as coordinator of the Cooperative Study of Secondary School Standards. Many of you, I am sure, are more or less familiar with that study. One of the very important areas which was extensively evaluated was that of the secondary school library. The method of evaluation and presentation of results is set forth in the special publication How to Evaluate a Secondary School Library. It was also presented briefly, with illustrative "educational thermometers," in two articles in the A.L.A. Bulletin. In this method we tried by means of an extensive group of measures -numerical, qualitative, and judgmental -to judge not only the extent, appropriateness, recency and adequacy of the book and periodical collections, and the adequacy, preparation, and qualifications of the staff, but also to measure the more important matters of organization, librarian's responsibilities to staff and students, selection of library materials, and use of library by both students and instructors.

We had hoped to apply the same method to a representative group of junior colleges, but were not able to obtain the funds to do this systematically. Several junior colleges, however, have found that a large percentage of the section on the secondary school library applies equally well to the junior college library. I suggest that you consider the use of part or all of this material in a conscientious effort to make a critical self-evaluation of your own library. I shall be surprised if you do not find many elements in this evaluative instrument which are a distinct incentive to improvement. Of course not all of the norms given would necessarily fit the junior college library. If a considerable body of junior colleges would apply them, however, it would not be difficult to build up special junior college norms on the measures used, particularly those involving numerical factors. In our study of "recency," for example, we asked each librarian to count the number of titles in the 300's and 500's of the decimal classification (social science and natural science), and the proportion of them which had been copyrighted in the past ten years. A summary of results for 200 secondary school libraries showed variation from one school which reported no books in these two classes in the past ten years to one (perhaps they had had a fire!) which reported Ioo per cent published in the same period. The typical or median for the 200 schools was 33 per cent, exactly one-third, of their books in these two important fields of social science and natural science in the past ten years. In only 30 of the 200 schools were half or more of the books published during the last decade. Are these suitable standards for junior colleges? I do not know. No one knows. By a little cooperative effort, however, it would be possible to compile information on actual practice in a representative group of junior colleges. Surely a junior college library should not be less up to date than that of a secondary school.

We need definite statements of junior college norms as well as standards. Statements of standards, where we should be, have been formulated by various groups including your own. We also need statements of norms, where we are. These norms should be formulated not only for junior colleges as a whole, but for institu- 
tions of different types, different sizes, different methods of control. We need to know clearly where we are (norms) before we can make intelligent progress toward where we should be (standards). Perhaps, too, a realistic contemplation of actual practice may cause us to modify in some cases the statements of theoretically derived standards. Granting that the norm (the 50-percentile) is probably far too low in many library measures, it may be much better as a practical matter to aim at a tentative standard such as the 75-percentile norm, than to aim at an ideal, theoretically formulated standard which may be so far out of reach as to discourage, if not prevent, any practical effort to reach it.

\section{Cooperation}

My final suggestion is a very concrete and practical one-for closer cooperation of your group with the American Association of Junior Colleges. The annual meetings of the association in the past have been too much meetings of administrators. Next year, February 27 to March I, the annual meeting is to be held, for the first time in thirteen years, at Chicago. No less than 122 junior colleges, with more than 25,000 students and more than 2500 instructors are located in Illinois and bordering states. We are planning a series of sections for instructors in the various subject matter fields-English, science, mathematics, etc.-also for counselors and librarians. I feel that such section meetings should not only be of distinct value to the librarians themselves, but should also aid in developing a library consciousness on the part of administrators. Our tentative plans call for two such meetings, one Friday afternoon, and one Saturday morning. For at least one of these we are suggesting the general topic, "The Implications of Our Field for Terminal Education." We would appreciate it if this library group, without in any way sacrificing your own identity, would undertake through a committee or otherwise, to arrange programs for these two sessions of a group of junior college librarians. I believe this would be a real forward step in junior college library consciousness and influence.

\section{Conclusion}

In my volume The Junior College published a decade age, I wrote:

The junior college library has not received the recognition and emphasis that it merits in most of the institutions of the country. Standards have been low, actuality has been lower, facilities have been inadequate, administrators have slighted it when budgets were made, and investigators have usually ignored it in published studies. In the university, in its emphasis on upper division and graduate specialization, the library is commonly recognized as the "throbbing heart" of the institution, indispensable to life and growth. In the junior college, in far too many cases, the pulsations have been weaker and the intellectual life has suffered accordingly.

As I look at conditions today, not through the eyes of a library specialist it is true, but through those of a layman vitally interested in the development of better library facilities and services in our junior colleges, I believe that marked improvements have been made. The pulsations have grown stronger. I am sure, however, that we may look forward to still greater improvements in the decade of the forties upon which we are now entering. The pulsations have a chance to be still further strengthened.

In this paper I have tried to suggest certain concrete improvements upon which 
this group might cooperate. I shall be very glad indeed if time permits a frank discussion of some of these, particularly of the suggestions for possible supplements to the Mohrhardt list, for the construction of a periodical scale, for a special library terminal education committee, for evaluation by the instruments devised by the cooperative study, for the development of norms for measuring the recency of a junior college book collection, and for the assumption of responsibility for a special library section at the next annual meeting of the American Association of Junior Colleges. I am not particularly happy to have attempted to present a paper before this group of professional librarians unless I have been able to make some suggestions which will result in your undertaking some new activities yourselves. You see, I am not quite sure that you are completely overworked after all! 